\title{
Foliar application of calcium improves growth, yield and quality of tomato cultivars
}

\author{
Muhammad Sajid, Izhar Ullah*, Abdur Rab, Syed Tanveer Shah, \\ Fazal-i-Wahid, Naveed Ahmad, Imran Ahmad, Asif Ali, Abdul Basit, \\ Fareeda Bibi and Masood Ahmad \\ Department of Horticulture, The University of Agriculture Peshawar-Pakistan \\ *Corresponding author's email: izharhorticons361@aup.edu.pk
}

Citation

Muhammad Sajid, Izhar Ullah, Abdur Rab, Syed Tanveer Shah, Fazal-i-Wahid, Naveed Ahmad, Imran Ahmad, Asif Ali, Abdul Basit, Fareeda Bibi and Masood Ahmad. Foliar application of calcium improves growth, yield and quality of tomato cultivars. Pure and Applied Biology. Vol. 9, Issue 1, pp10-19.

http://dx.doi.org/10.19045/bspab.2020.90002

\begin{tabular}{llll}
\hline \hline Received: 05/03/2019 & Revised: 20/08/2019 & Accepted: 28/08/2019 & Online First: 19/09/2019 \\
\hline
\end{tabular}

\section{Abstract}

Calcium plays an important role in plant life cycle as it influence intake of nitrogen and boron, promotes early roots formation and growth, reducing the incidence of blossom end rot, encourage seed and grain production, important for the cell at the apical growth of shoot/root, increase calcium content of food and feed crops. Keeping in view their significance, this research study was planned to examine the foliar application of calcium on quantitative and qualitative attributes of tomato cultivars. Tomato cultivars (Super Classic, Rio grand, Bambino and Roma) were sprayed with different calcium concentrations $(0,0.5,1.0$ and $1.5 \%)$ after transplanting and at fruit set stage. Regarding Cultivars, Riogrand had maximum survival percentage, plant height, number of branches, total yield, total soluble solid and fruit firmness with minimum days to flowering, days to fruit set and fruit infestation plot $^{-1}$. The foliar application of calcium @ 1.5\% significantly increased the plant height, number of branches, total yield, fruit firmness with minimum infected fruit plot $^{-1}$ and TSS content. The foliar application of $\mathrm{CaCl}_{2} @ 1.5 \%$ reduced the intensity of fruit infestation in cultivar Rio grand as compared to untreated plants of cultivar Roma VF. It was concluded that the tomato cultivar Rio grand should be sprayed with calcium @ 1.5\% for better growth, yield, quality and minimal blossom end rot infestation of tomato under the agro-climatic condition of Swat valley.

Keywords: Blossom end rot; Cofactor; Lycopene, Nutrient availability; Structural integrity

\section{Introduction}

Tomato (Lycopersicon esculentum Mill.) belongs to the family solanaceae.The genus Lycopersicon consists of annual and short lived perennial herbaceous plants. It is originated in tropical America where it was locally known as tomtit. After Europe tomato was taken to Asia from Mexico. Tomato is a typical day neutral plant and is mainly self-pollinated with diploid chromosome number $(2 n=24)$. It is a warm season crop reasonably resistant to heat and drought and grown under wide range of soil and climatic conditions. Tomato is native of the west coast of south america (Mexico and Peru) and was cultivated by the Red Indians about 500 B.C long before the arrival of spaniards.In world vegetable production tomato rank next to potato. Tomato contain important mineral and antioxidant such as carotenoids, lycopene, vitamin $\mathrm{C}$ and $\mathrm{E}$ [1] and phenolic 
compounds which play a vital role in human nutrition to reduce chances of cardiovascular disease and certain cancer disease. Tomatoes are used in various ways such as sun dried tomatoes, tomato sauces, tomato juice, tomato soup, tomato ketchup and fresh tomato as salad [2].In Pakistan, area under tomato cultivation was 53.40 thousand hectares with the total production of 561.90 thousand tones, In which Khyber Pukhtunkhwa contributed 16.50 thousand hectares that have a production of 161.80 thousand tones with an average yield of 9.8 tons ha ${ }^{-1}[3]$.

However sandy loam soil is considered best for early crop. Highest yields can be obtained by growing tomato in loam, clay loam and silty loam having enough organic matter [4]. Optimum amount of nutrients are required for better growth and higher yield of tomato. For good yield, 20-25 ton hawell rotten Farm Yard Manure should be incorporated in the soil at the time of soil preparation. About $80 \mathrm{~kg} \mathrm{ha}^{-1} \mathrm{P}$ and $40 \mathrm{~kg}$ $\mathrm{ha}^{-1} \mathrm{~K}$ should be applied at the time of transplanting while $100 \mathrm{~kg}$ of $\mathrm{N}$ should be applied in three split doses [5].Generally, a balanced supply of nutrients is essential for optimum yield and fruit quality. Calcium is an important nutrient that plays a key role in the structure of cell walls and cell membranes, fruit growth and development, as well as general fruit quality [6]. It enhances resistance to bacterial and viral diseases. The Ca taken up from the soil is translocated to the leaves but very little goes from the leaves to the fruit (7). Therefore, plants need a constant supply of $\mathrm{Ca}$ for vigorous leaf and root development and canopy growth [8]. Calcium increase cell wall thickness and strengthens the cell. As an important component of cell wall, calcium availability significantly strengthen the cell wall and enhances structural integrity of stem and quality fruit. Calcium deficiency results in more than 30 disorders in various crops. Calcium deficiency not only cause physiological disorders but also influence some aspects particularly in fruits such as decline in respiration rate, delaying ripening, enhancing shelf life, vitamin C contents and fruit firmness [9]. The soluble calcium fertilizer, either calcium nitrate or calcium chloride precipitates carbonate component from the solutions as a calcium carbonate. Ultimately, the $\mathrm{pH}$ of concentrated fertilizer solution is reduced and less ammonia is lost [10]. Calcium also plays a vital role in enhancing cell wall integrity, cell growth, cell division, nitrogen assimilation and acting as a cofactor for some enzymes [11]. The present research study was planned out to find out the best high yielding tomato cultivar under optimum concentration of calcium application.

\section{Materials and methods}

\section{Experimental site and design}

This present research study was investigated at Agricultural Research Institute (North) Mingora, Swat (35 ${ }^{\circ} 22^{\prime}$ $42^{\prime \prime}$ North, $72^{\circ} 10^{\prime} 47^{\prime \prime}$ East) during summer 2012. The experimental was conducted in Randomized Complete Block Design with two factor factorial arrangement i.e Tomato cultivars (Super Classic, Rio-grand, Bambino and Roma) and different concentration of calcium $(0,0.5,1.0$ and $1.5 \%)$ having three replication.

Experimental treatment and procedure There were sixteen (16) treatments in each replication. The distance between plant to plant and row to row $10 \mathrm{~cm}$ and $30 \mathrm{~cm}$ away from each other respectively. Each replication was consisting of four sub plots each of size $4 \times 4 \mathrm{~m}^{2}$. Each sub plot consisting of four ridges and ten plants in each ridge were transplanted. Tomato cultivars (Super Classic, Rio-grand, Bambino and Roma) were sprayed with different concentration of calcium $(0,0.5$, 1.0 and $1.5 \%$ ) after transplanting and at fruit set stage as a foliar spray to minimize the incidence of blossom end rot disorder.

\section{Field preparation}

Soil was ploughed and leveled through leveling machine. Soil texture was improved by the application of recommended dose of well rotten farm yard manure $\left(20\right.$ tonsha $\left.^{-1}\right)$. Urea $(46 \% \mathrm{~N})$ as a 
source of Nitrogen, was given in three split doses to prevent leaching. The recommended dose of nitrogen for tomato crop (112 $\left.\mathrm{kgha}^{-1}\right)$ was applied at transplantation time and after transplantation two other doses were applied. Phosphorous @ $80 \mathrm{kgha}^{-1}$ along with potassium @ $40 \mathrm{~kg} \mathrm{ha}^{-1}$ were supplied to the soil prior to transplantation. Before fertilizer application, soil sample was analyzed for different nutrients.

\section{Calcium levels preparation}

For preparing the required Calcium level, Formula mass of $\mathrm{CaCl}_{2}$ is $111 \mathrm{~g}$ which contain $36 \%$ calcium and $64 \%$ chlorine by weight. For preparing $1 \%$ calcium solution, $22.7 \mathrm{~g}$ of calcium chloride were dissolved in $972.3 \mathrm{ml}$ water respectively and same procedure were used for other treatments. The physico-chemical analysis of soil sample of experimental plots observed $(0.151 \% \mathrm{~N})$, lime (12.7\%), $\mathrm{pH}(7.81)$, Phosphorous (2.4\%) and Potassium (0.009\%).

\section{Transplantation of seedlings}

The seedlings of equal height and vigor were transplanted to the experimental field at evening time. The seedlings were immediately irrigated after transplantation and the subsequent irrigations were done after ten days interval. Different cultural practices i.e. hoeing, weeding, etc were performed regularly throughout the experiment. The data on various growth and yield parameters of tomato cultivars regarding calcium treatment as foliar spray were collected on the following parameters. Survival percentage of tomato plant in each treatment of every replication was calculated by using following formula:

$$
\text { Survival }(\%)=\frac{\text { No. of } \text { survived plants }}{\text { Total No. of plants }} \times 100
$$

Days were counted from day of transplanting to $1^{\text {st }}$ flower appearance in all treatments of each replication, and then their means were calculated. Means were computed by counting number of days from days to first flowering up to $1^{\text {st }}$ fruit set in all treatments of each replication. Plants height $(\mathrm{cm})$ were calculated by using measuring tape in each treatment from 5 plants randomly selected plants and calculated their means. No. of branches plant $^{-1}$ were counted in all treatment of every replication and their average were taken. The total productivity was recorded by the following formulae:

$$
\text { Yield tons ha } \mathrm{ha}^{-1}=\frac{\text { Yield of sub plot }(\mathrm{kg})}{\text { Area of sub plot }\left(\mathrm{m}^{2}\right) \mathrm{X1000}} \times 10000\left(\mathrm{~m}^{2}\right)
$$

Percent infected fruit of each treatments in

following formula:

each replication was calculated by using

$$
\text { Percent infected fruit plot }-1=\frac{\text { No. of infected fruits }}{\text { Total fruit }} \times 100
$$

Fruit firmness $\left(\mathrm{kg} . \mathrm{cm}^{-2}\right)$ was measured with help of Penetrometer. The probe of the penetrometer was inserted for measuring fruit firmness and readings of each treatment were taken in $\mathrm{kg} . \mathrm{cm}^{-2}$ [12].Total soluble solids content ( $\left.{ }^{\circ} \mathrm{Brix}\right)$ in fruit juice was determined through hand refractometer according to procedure described by
[13].Data was analyzed using statistical tool MSTATC for calculating ANOVA and LSD value at 5\% level of significance [14]. Results and discussion Survival percentage

It is obvious from (Table 1) that the survival percentage was significantly affected by tomato cultivars, while calcium application 
and the interaction between cultivar and calcium on survival percentage was found non-significant. The highest survival percentage $(89.33 \%)$ was observed in cultivar Rio-grand followed by cultivar Bambino (86.13\%), while less survival percentage $(78.56 \%)$ was observed in cultivar Roma VF (Figure 1). Balanced supply of nutrients is essential for optimum yield and fruit quality. Calcium is an important nutrient that plays a key role in the structure of cell walls and cell membranes, fruit growth and development, as well as general fruit quality [7]. It enhances resistance to bacterial and viral diseases [15] Variation in the survival percentage of tomato cultivars might be due to variability in environmental conditions of the area, including the temperature and humidity. Proper temperature is necessary for more number of plants to survive because the seedling transplanted are very sensitive to temperature shocks as in both extreme case the temperature affects the survived plants. Similarly, proper humidity also affects the percent survival of the plants because high relative humidity causes the seedling damping off which ultimately results in death of the transplanted seedlings. The differences in survival percentage amongst various tomato cultivars could be due to genetic variability of the selected cultivars and their adoptability to particular environment [16].

\section{Days to first flowering}

Data presented in Table 1 showed that various tomato cultivars had a significant response to days to first flowering, while the calcium application and their interaction non-significantly influenced the number of days to first flowering of tomato. Regarding cultivars, less number of days to first flowering were taken by cultivar Riogrand (30.49 days) followed by plants of cultivar Bambino which took (34.44 days) days to first flowering. Cultivar Roma VF took the highest number of days to flower (40.26 days) (Figure 1). Flowering is key factor which influence the fruit set and is mainly dependent on photoperiod and temperature. Tomato is a day neutral fruit vegetable crop [17]. Early flowering in cultivar Rio-grand might be due to genetic variation among different tomato cultivars. As far as temperature is concerned, tomato is warm season crop which requires $18-25{ }^{\circ} \mathrm{C}$ for normal growth. More number of days to flowering might be due the cloudy weather and low temperature during the flowering period in the experimental trial. This is also confirmed by the [18] that flowering plants responded to external as well as internal stimuli which produced endogenous compounds responsible for the induction of flowers. The results were also in proximity with the findings of [19] who found that blooming period was in the range of 17 to 31.25 days in different cultivars.

\section{Days to fruit set}

Table 1 indicated that tomato cultivars had a significant effect on number of days to fruit set, while the foliar application of calcium and interaction of calcium and cultivars had non-significant effect on days to fruit set. Less number of days to fruit set (46.03) were taken by cultivar Rio-grand as compared to cultivar Roma VF (55.31) and cultivar Super Classic (51.45) (Figure 1). Fruit set is the key factor for yield and is mainly concerned with flowering. The reason for variation in number of days to fruit set could be attributed due to different response of tomato cultivars to light and temperature and also due to the genetic variation of the selected tomato cultivars. Proper amount of carbohydrates are essential to be available for fruit set. Therefore, plants responding well to light do more photosynthesis and as a result more photosynthate is available for fruit setting. Plants utilize the excessive carbohydrates for reproductive purposes. Proper temperature is also essential for photosynthesis and fruit set occurrence because photosynthesis decreases with increase in temperature. Temperature affects the fruit set in the sense that higher temperature cause the drying of stigma surface and becomes non receptive for 
pollen grains which leads to failure of pollination and fertilization and ultimately leads to fail the fruits to be set. The results were in contrast with the findings of [19, 20] who recorded that minimum and maximum time of 25 and 41 days respectively for fruit setting in different tomato cultivars.

\section{Plant height (cm)}

Data presented in Table 1 revealed that cultivars and different levels of calcium had a significant effect on the plant height, while their interaction was found nonsignificant. Taller plants $(97.0 \mathrm{~cm})$ were observed in Rio-grand followed by Bambino (95.2 cm). While the shorter plant $(90.6 \mathrm{~cm})$ was found in cultivar Roma VF. Regarding various levels of calcium. The plant height increased from 90.0 to $97.53 \mathrm{~cm}$ with increasing the calcium levels from 0 to $1.5 \%$ (Figure 1). Plant height is one of the important growth attributes which influence the yield. The differences in the plant height among various tomato cultivars might be due to their genetic potential. The increasing tendency in plant height was similar with the findings of [21, 22] observed differences in plant height among cultivars of tomato put under evaluation and screening trial. Calcium is an important constituent of cell and it also regulates the cell lengthening of root and shoots. Highest plants might be due to the reason that calcium regulates the uptake of certain nutrients like boron and nitrogen in nitrate form and also reduced the loss of nitrogen. Plant height is vegetative feature and the reason for the variation in the plant height might be due to the ability of cultivars for nutrient uptake like nitrogen which enhanced the vegetative growth and ultimately enhanced the plant height. Previous research showed that calcium is important for regulation of meristematic growth as it is important in maintenance and regulation of lamellary system in cell organelles. The obtained results may be due to the role of $\mathrm{Ca}$ in cell division, mitosis and carbohydrate metabolism [23].

\section{No. of branches plant ${ }^{-1}$}

Tomato cultivars subjected to different calcium levels exhibited significantly influence on No. of branches plant ${ }^{-1}$, whereas their interaction was found nonsignificant (Table 1). Maximum number of branches plant ${ }^{-1}$ (7.32) was recorded in cultivar Rio-grand followed by cultivar Bambino (6.32), while minimum number of branches plant $^{-1}$ (4.84) was observed in cultivar Roma VF. Regarding calcium levels application, more number of branches plant ${ }^{-1}$ (7.26) was observed in plants sprayed with $1.5 \%$ calcium as compared to $1 \%$ Calcium (6.22) and control treatment (4.7) (Figure 1). The reason for the differences in the No. of branches plant ${ }^{-}$ ${ }^{1}$ could be attributed that different tomato cultivars had different morphological characters like plant height and number of branches. As calcium play an important role in uptake of certain nutrients like nitrogen and boron. Nitrogen enhanced the vegetative growth. Increase in vegetative growth resulted production of more branches plant ${ }^{-1}$. The present results are in line with findings of [24] who reported that different morphological characters like plant height and number of branches plant ${ }^{-}$ ${ }^{1}$ were different for different cultivars which influenced yield through number of fruits and fruit characters.

\section{Total yield (tha ${ }^{-1}$ )}

The statistical analysis of the data indicates that tomato cultivars and calcium levels had a significant effect on total yield whereas their interaction was found non-significant (Table 1).The highest total yield (23.77 $\mathrm{t} \mathrm{ha}^{-}$ $\left.{ }^{1}\right)$ was obtained from cultivar Rio-grand followed by cultivar Bambino (22.38 $\left.\mathrm{t} \mathrm{ha}^{-1}\right)$ whereas the lowest yield ha ${ }^{-1}\left(19.45 \mathrm{t} \mathrm{ha}^{-1}\right)$ was noted in cultivar Roma VF. Regarding calcium level application, higher total yield (23.38 $\mathrm{t} \mathrm{ha}^{-1}$ ) was observed when the tomato plants were sprayed @ 1.5\% calcium as compared to total yield $(21.92 \mathrm{t}$ $\mathrm{ha}^{-1)}$ at $1 \%$ Calcium and control treatments (20.05 $\mathrm{t} \mathrm{ha}^{-1}$ ) (Figure 1). Yield is economical feature of crop. The reason for increase in yield might be that calcium has 
a vital role in meristem growth, cell elongation and nutrient uptake like nitrogen which enhanced the vegetative growth and ultimately lead to more number of leaves. The increase in number of leaves enhances the amount of photosynthetic material which resulted in higher yield. [25] Reported that a significant variation regarding total yield and growth attributes of tomato was recorded among different tested cultivars. The morphological characters like plant height and number of branches are known to influence the yield through the number of fruits and fruit characters [26]. It was observed that yield increased with calcium application. Our results are in accordance with the findings of [27] who found that the tomato produced the highest yield when calcium was used @ $300 \mathrm{mg} \mathrm{L}^{-1}$ than $150 \mathrm{mg} \mathrm{L}^{-1}$. These results are also in accordance with [28] who concluded that production and other quality parameter were significantly affected by calcium fertilization and their deficiency caused reduction in yield.

\section{Percent infected fruits plot $^{-1}$}

Table 1 showed that percent infected fruits plot $^{-1}$ was significantly affected by cultivars, foliar application of calcium and their interaction. The highest fruit infestation $(1.70 \%)$ was recorded in cultivar Roma VF as compared to cultivar Rio-grand $(0.96 \%)$. Similarly number of fruit infestation $(1.65 \%)$ was found maximum in untreated plants with calcium which was significantly reduced by increasing the calcium level up to $1.5 \%$ (1 $\%$ ) (Figure 1). As compared to interaction, more number of infected fruits $(1.89 \%)$ were observed in cultivar Roma in control plot, whereas less percent infected fruits $(0.52 \%)$ were found in tomato cultivar Riogrand treated with $1.5 \%$ calcium as foliar spray (Figure 2). The difference in percent infected fruits plot $^{-1}$ in relation to different tomato cultivars might be due to their resistance to the disorder and environmental condition which varied the degree of infestation but however, it is interesting to know that tomato cultivar
'Roma' (the cultivar under trial) is highly susceptible to blossom end rot [28]. Calcium is the one of the important nutrient that maintains the cell integrity and cell structure which enhanced the fruit quality by increasing the fruit firmness. Foliar application of calcium significantly reduced the blossom end rot. [27] Observed that calcium application affected yield and quality parameter, further calcium deficiency reduces yield while less fruit firmness, high fruit cracking and more blossom end rot was recorded in calcium deficient plants. The results are also in close proximity with findings of [29] that regular irrigations and calcium along with phosphorus fertilizer controlled the blossom end rot infestation.

\section{Fruit firmness $\left(\mathrm{kgcm}^{-2}\right)$}

Data presented in (Table 1) that calcium application significantly influenced the fruit firmness, while tomato cultivar and the interaction of cultivar and calcium exhibited no significant effect on the fruit firmness of tomato. Increasing calcium level increased the fruit firmness. Highest fruit firmness $\left(2.88 \mathrm{~kg} \mathrm{~cm}^{-2}\right)$ resulted in plants applied @ 1.5\% calcium, whereas lowest value of fruit firmness $\left(2.34 \mathrm{~kg} \mathrm{~cm}^{-}\right.$ ${ }^{2}$ ) was observed in fruits of untreated plants (Figure 1). Fruit firmness is important quality parameter which is influenced by the foliar application of calcium application. As calcium play a vital function in up keeping of cell and retain its structure by joining the pectin component in the cell. Calcium pectate which is important cell component and play key role in postponing the degradation process. Senescence can also be control by maintaining optimum calcium level in the fruit. The results are in accordance with findings of [27] who reported softness of fruits in calcium deficit plant and positive interaction between fruit firmness and calcium application. These findings are in accordance with findings of [30] who observed an increase in fruit firmness when calciumwas applied @ 300 mg L-1. 


\section{Total soluble solid ( ${ }^{\circ}$ Brix)}

It is obvious from (Table 1) that maximum value of TSS content (4.10 ${ }^{\circ}$ Brix) was observed in cultivar Riogrand followed by Bambino (3.54 ${ }^{\circ}$ Brix), while minimum total soluble solid content $\left(2.56{ }^{\circ}\right.$ Brix $)$ was recorded in Roma VF. The TSS content of tomato fruit decreased with increasing the concentration of calcium as foliar spray. TSS content of tomato decreases from 3.86 to $2.63{ }^{\circ} \mathrm{Brix}$ with increasing calcium level application from 0 to $1.5 \%$ (Figure 1). The highest total soluble solid content in fruits of untreated plants and the lowest total soluble solid in fruits of plants treated with $1.5 \%$ calcium might be due to conversion of starch to sugars. This change from starch to sugars precedes the fruit maturity. Calcium deficit fruits are very susceptible to ripening which can be control by maintaining optimum calcium level in the fruits. The present results confirms the findings of the [31] who observed that total soluble solid content of tomato fruits were highly affected by $\mathrm{CaCl}_{2}$ application in the storage condition, increasing the calcium concentration resulted a decrease in the total soluble solid content of tomato fruits. This is also confirmed by [32] who reported that decreased in TSS content by increasing $\mathrm{Ca}\left(\mathrm{NH}_{3}\right)_{2}$ and higher TSS content with low $\mathrm{Ca}\left(\mathrm{NH}_{3}\right)_{2}$ concentration.

Table 1. Mean Square values of growth, yield and quality attributes as affected by tomato cultivars and foliar application of calcium

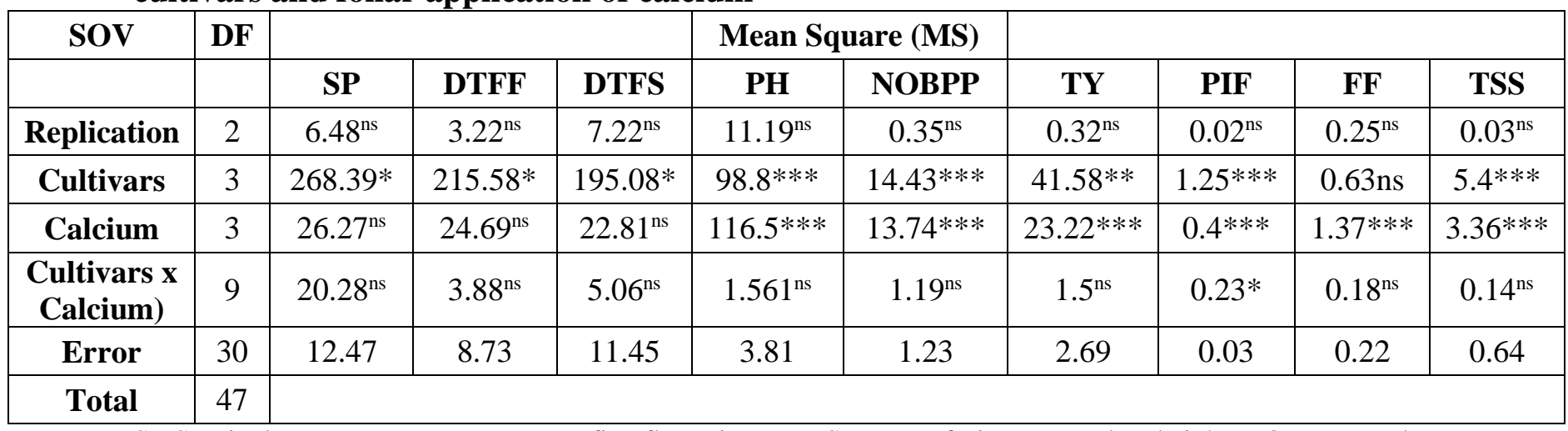

SP:Survival percentage; DTFF:Days to first flowering; DTFS:Days to fruit set; PH:Plant height; NOBPP:Number of branches per plant; TY:Total yield; PIF:Percent infected fruit; FF:Fruit firmness; TSS:Total Soluble solid $* * *: \mathrm{P} \leq 0.001 ; * *: \mathrm{P} \leq 0.01 ; \mathrm{P} \leq 0.05 ;$ ns:Non significant 
(a)
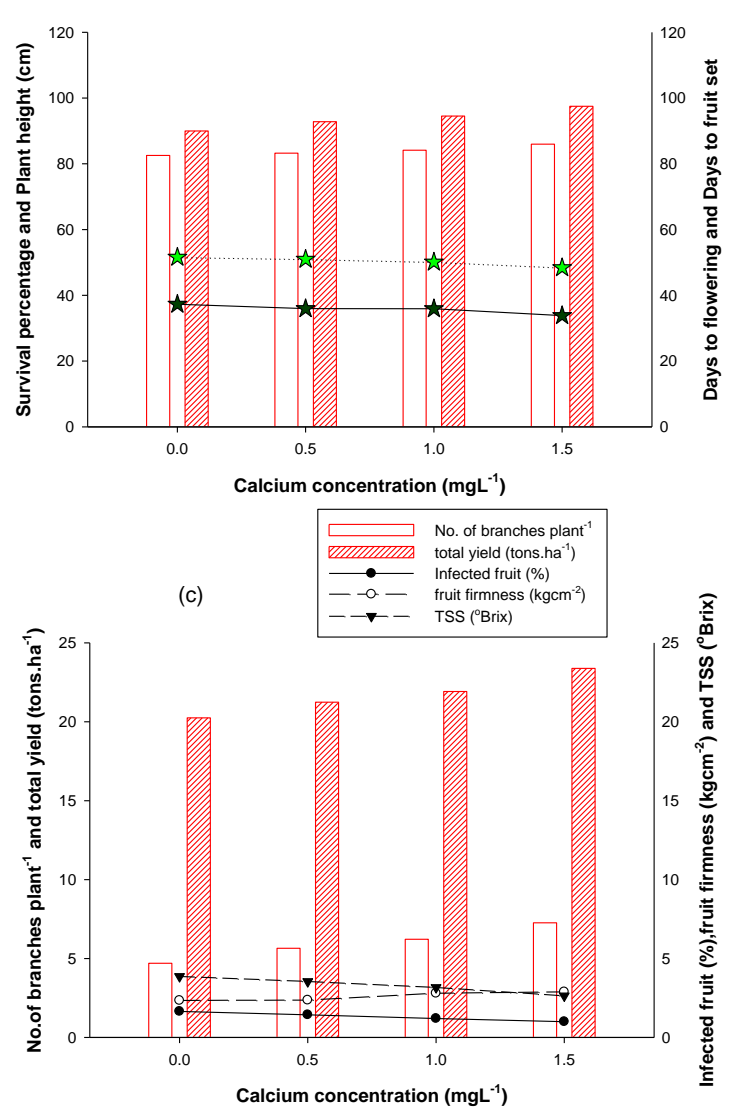

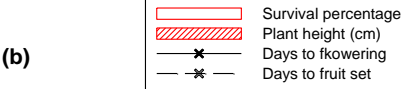

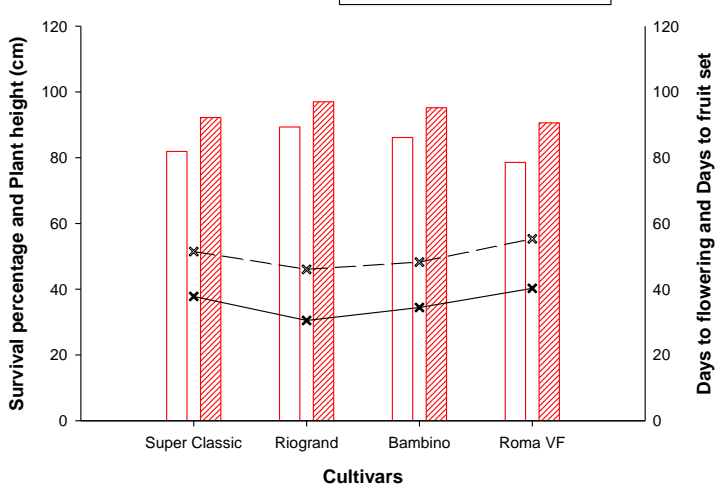

(d)
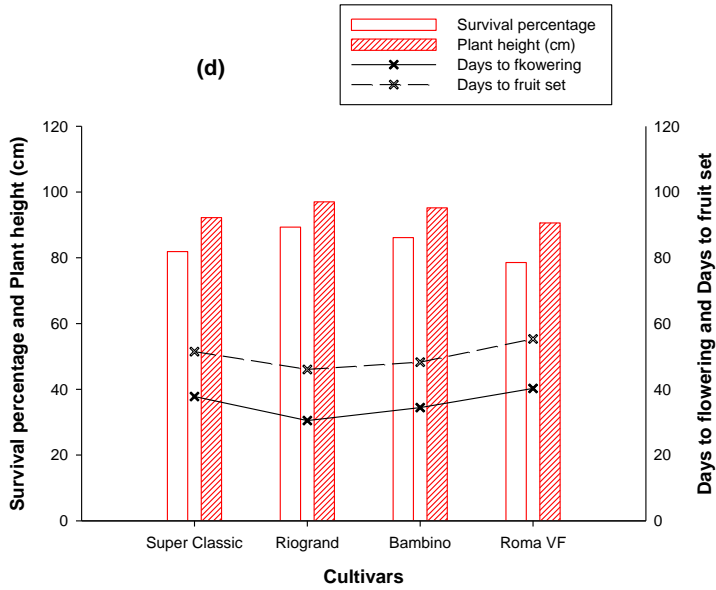

Figure 1. Growth, yield and quality attributes of tomato as affected by cultivars and foliar application of calcium

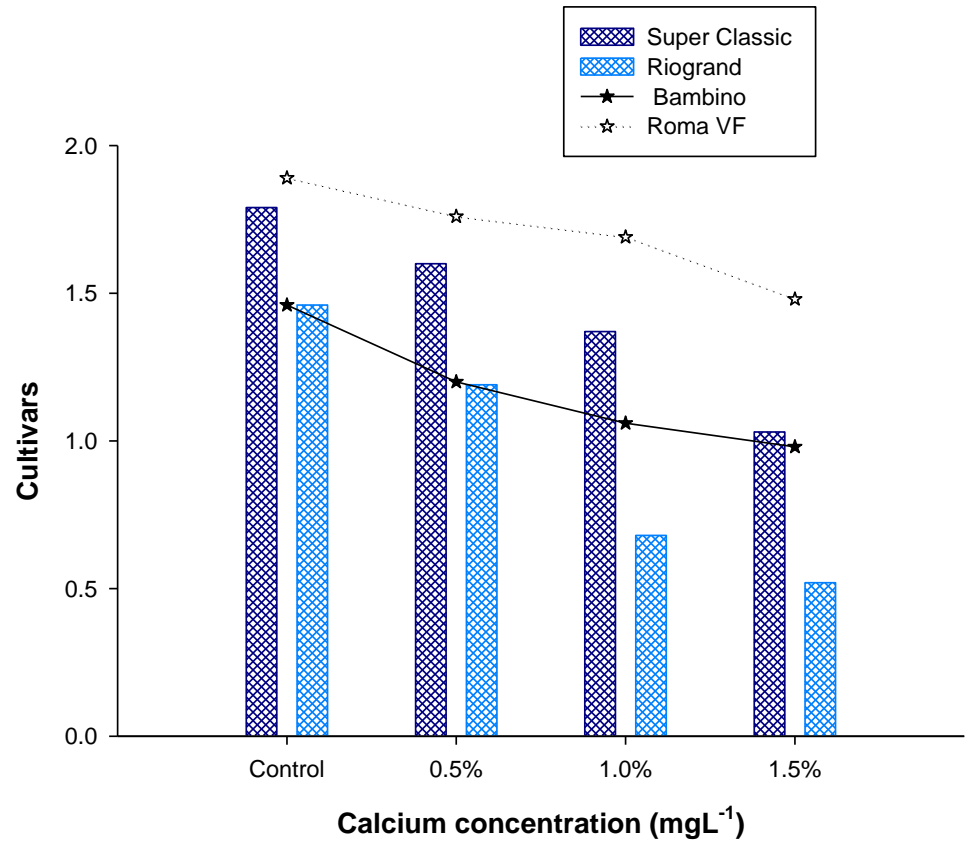

Figure 2. Percent infected fruit plot $^{-1}$ of tomato as affected by interaction between cultivars and foliar application of Calcium 


\section{Conclusion}

Rio-grand cultivar showed best response to growth attributes and yield among different cultivars of tomato. Calcium levels were found effective in reducing blossom end rot of tomato fruits as compared to control, whereas calcium level $1.5 \%$ was found more effective among all levels. The tomato cultivar Rio-grand and foliar application of Calcium @ $1.5 \%$ is recommended for better yield and quality production of tomato under the agroclimatic condition of northern region Swat valley.

\section{Authors' contributions}

Conceived and designed the experiments: A Rab, Performed the experiments: A Ali, Analyzed the data: I Ahmad \& F Wahid, Contributed materials/ analysis/ tools: N Ahmad \& Fareeda Bibi, Wrote the paper: I Ullah, M Sajid \& A Basit, Review the article: M Sajid \& M Ahmad.

\section{References}

1. Adalid AM, Rosello $\mathrm{S} \&$ Nvez $\mathrm{F}$ (2009). Producing tomato for their high nutritional value. Recent Res and Devel in Plant Sci 2: 33-52.

2. Frusciante L, Carli P, Maria R, Ercolone S, Perice R, Matleo AD, Fogliano V \& Pellogrini N (2007). Antioxidant nutritional quality of tomato. Mol Nutr and Food Res 51(5): 609-617.

3. Minfa (2010). Pakistan statistical year book. Federal bureau of statistics. Ministry of economic affairs and statistics government of Pakistan: 5455.

4. Baloch A (1994). Vegetable crops. Horticulture National Book Foundation. Islamabad, pp 489-509.

5. Malik MN (1994). Horticulture, Plant environment. National book foundation Islamabad, pp 216-220.

6. Kadir SA (2004). Fruit quality at harvest of 'Jonathan' apple treated with foliar applied calcium chloride. $J$ of Plant Nutr 27: 1991-2006.
7. Usten NH, Yokas AL \& Saygili H (2006) Influence of potassium and calcium level on severity of tomato pith necrosis and yield of greenhouse tomatoes. ISHS Acta Hortic 808: 345350.

8. Del-Amor FK \& Marcelis LFM (2003). Regulation of nutrient uptake, water uptake and growth under calcium starvation and recovery. $J$ of Horti Sci and Biotechnol 78: 343-349.

9. Bangerth F (1979). Calcium-related physiological disorders of lants. Ann Rev of Phytopathol 17: 97-122

10. Easterwood DGW (2002). Calcium's role in plant nutrition. Fluid $J$ 26(2): 161-168

11. Hudson TH, William JF \& Aton MK (1981). Plant science growth, development and utilization of cultivated plants. By Prentic Hall, Inc. Englewood Cliffs, N.J. 07632, pp 676.

12. AOAC (1990). Association of Official Agriculture Chemist Official Methods of Analysis. $9^{\text {th }}$ Ed. 832

13. Pocharski WJ, Konopacka D \& Zwierz J (2000). Comparison of MagnessTaylor pressure test with mechanical, non-destructive methods of apple and pear firmness measurements. Intl Agrophy 14: 311-31

14. Jan MT, Shah P, Hollington PA, Khan MJ \& Sohail Q (2009). Agriculture Research: Design and Analysis, A Monograph. NWFP Agric. Univ. Pesh. Pak.

15. Usten NH, Yokas AL \& Saygili $\mathrm{H}$ (2006). Influence of potassium and calcium level on severity of tomato pith necrosis and yield of greenhouse tomatoes. ISHS Acta Horticul 808: 345-350

16. Khan SA, Kashif $\mathrm{R}$ \& Yaseen $\mathrm{M}$ (2001). The extent of inbreeding depression in seven cultivars. Intl $J$ Agric Biol 3(4): 498-500.

17. Malik MN (1994). Horticulture. Vegetable crops. National book foundation Islamabad, pp 509. 
18. Jaha JC \& Krishi B (2001). Studies on performance of different tomato hybrids in offseason under different planting method in Terai agro-climatic zones of west Bangal. West Bangal $J$ Inter Academicia 5(2): 186-189.

19. Halfacare RG \& Barden JA (1979). Horticulture. New York: McGrawHill. Hanger BC (1979). The movement of calcium in plants commun. Soil Sci Plant Anal 10(1,2): 171-193.

20. Khokhar KM, Hussain SI, Qureshi KM, Mahmood T \& Niazi ZM (1988). Studies on production of tomato cultivars in summer season. Pak $J$ Agric Sci 25: 65-69.

21. Chaudry MF, Khakhar KM, Hussain SI, Mahmood T \& Iqbal SM (1999). Comparative performance of some local and exotic tomato cultivars during spring and autumn seasons. Pak $J$ Arid Agric 2: 7-10.

22. Jaha JC \& Krishi B (2001). Studies on performance of different tomato hybrids in offseason under different planting method in Terai agro-climatic zones of west Bangal. West Bangal J Interacademicia 5(2): 186-189

23. Manoj R \& Roghav M (1998). Performance of $F_{1}$ hybrids and high yielding varieties of tomato under mid-west plains of Uttar Pardesh. Progressive Hort 30(3):194-197.

24. Davis JM., Sanders DC, Nelson PV, Lengnick L \& Sperry WJ (2003). Boron improves the growth, yield, quality and nutrient content of tomato. J American Soc Horticult Sci 128: 441446.

25. Bokkisam HB (2007). Effect of $\mathrm{N}$ and $\mathrm{K}$ ratios on yield and quality of chilli on vertisol in northern transitional zone of Karnataka. A Thesis submitted to the Uni. Agri. Sci. Dharwad, Ind.

26. Rida AS, Muhammad AA, Ereifij IE \& Hussain A (2002). Evaluation of thirteen open pollinated cultivars and three hybrids of tomato for yield, physiological disorder, seed production and vegetative growth. Pak J Agric Res 17(3): 290-296.

27. Peyvast G, Olfati JA, Kharazi PA \& Shahmaleki SK (2009). Uptake of calcium nitrate and potassium phosphate from foliar fertilization by tomato. J Hort Forestry 1(1): 7-13.

28. Serrano M, Amoras A, Pretal MT, Madrid R \& Romojaro F (2002). Effect of calcium deficiency on melon texture and glassiness incidence during ripening. J. Food Sci Technol Intl 8(3): 147-154.

29. Fernades HSA, Pereira D, Das DSB \& Assis VLGDE (1984). Reaction of tomato cultivars (Lycopersicon esculentum Mill.) to blossom end rot involving levels of calcium. Bio. Absts (1/4):35-39.

30. Venezuela Serivicio \& Para El Agriculture (1973). How to prevent tomato blossom end rot. Noticias Agricolas 6(36): 145-146. Hao X \& Papadopoulos AP (2002). Effect of calcium and magnesium on growth, fruit yield and quality in a fall greenhouse tomato crop grown on rock wool. Can J Plant Sci 83: 903-912.

31. Pila N, Gol BN \& Rao TVR (2010). Effect of post-harvest treatments on physicochemical characteristics and shelf life of tomato (Lycopersicon esculentum Mill.) fruits during storage. American-Eurasian J Agric \& Environ Sci 9(5): 470-479.

32. Plese, LPM, Tiritan CS, Yassuda EI, Prochnow LI, Corrente JE \& Mello SC (1998). Effect of application of calcium and boron on occurrence of blossom end rot on tomato grown in green house. Scientia-Agricola 55(1): 144-148. 